Ritrýnd grein birt 31. desember 2018

\title{
Laxdæla sem fóður fyrir gagnrýna hugsun
}

\author{
Ólafur Páll Jónsson
}

Abstract

- Um höfundinn

About the author

- Heimildir

Fornbókmenntir gefa tilefni til margvíslegra rökræðna um flókin álitamál af ýmsu tagi og henta pví ágæetlega til að pjálfa nemendur í gagnrýninni hugsun. Ritverk eins og Laxdala saga er raunar sérstaklega ákjósanlegt sem tæki til að pjálfa gagnrýna hugsun grunnskólanema. Fjallað er um tvær hliðar pessa máls; sú fyrri er heimspekileg og varðar sjálfa hugmyndina um gagnrýna hugsun, sú síðari er verkleg og lýtur að veruleika ofhlaðins skóla sem parf að sinna ótal viðfangsefnum á sama tíma, hefur takmörkuð námsgögn, býr við mjög stýrt skipulag, og hefur yfir að ráða kennurum sem hafa ekki endilega pælt mikið í gagnrýninni hugsun.

Gagnrýnin hugsun er færni sem gerir ráð fyrir tilteknum vitsmunadygðum, siðferðisdygðum og verknaðardygðum. Djálfun í gagnrýninni hugsun fellur pannig innan pess sem kallað hefur verið skapgerðarmenntun eða mannkostamenntun (e. character education). En hefur Laxdaela einhverja kosti fram yfir aðrar bókmenntir sem kennsluefni í gagnrýninni hugsun? Svar við pessari spurningu lýtur að verklegri hlið viðfangsefnisins. Laxdæla hefur verið lesin í skólum í fjölmörg ár og er líkleg til að halda peirri stöđu í náinni framtíð. Gera má söguna að námsefni skóla án pess að leggja eitthvað nýtt inn í skólastarfið, raunhæft er að búa til stuðningsefni án pess að pað úreldist á skömmum tíma, skólar eru líklegir til að eiga bekkjarsett af bókinni, kennarar kannast við söguna og vitað er hvaða aldurshópur ræður við hana. Dessa kosti hefur Laxdala umfram margar aðrar bækur. Auk pess er sagan margræð og fjallar um málefni sem brenna á ungmennum; hún fjallar um vináttu, trúmennsku, heiðarleika, sáttfýsi og samskipti, og líka um hatur, sviksemi, lygar og blekkingar, óheiðarleika, heift og hefnigirni.

Ef saga eins og Laxdcela er lesin sem opið tilboð um samræður um dygðir og lesti hefur pað áhrif á stöðu kennarans. Annars vegar er kennarinn sérfræðingur sem pekkir söguna, velur orð og hugtök sem notuð eru til að opna söguna, stýrir yfirferð og skilgreinir pau verkefni sem eru unnin. Á hinn bóginn býr kennarinn ekki yfir „hinni réttu túlkun“ eða ,veit hvert rétta svarið er“ heldur er hann jafningi nemenda í peim pælingum sem sagan gefur tilefni til. Ein leið til að komast út úr einhliða miðlun í kennslu yfir í gagnrýnar samræður er að taka skáldverk, sem kalla á róttæka túlkun og par sem enginn endir er á peim spurningum sem kunna að vakna, og nálgast pað sem opið tilboð um samræðu.

Efnisorð: Laxdæla saga, gagnrýnin hugsun, mannkostamenntun, dygðir, siðferðilegt uppeldi. 


\section{Inngangur}

Eru fornbókmenntir eins og Laxdala heppilegar til að kenna og pjálfa gagnrýna hugsun í grunnskólum? Stutta svarið er ,já“, fornbókmenntir, eins og margar aðrar góðar bókmenntir, gefa tilefni til margvíslegra rökræðna um flókin álitamál af ýmsu tagi og eru pví ágætlega til pess fallnar að pjálfa nemendur í gagnrýninni hugsun. En petta svar segir okkur ekkert um pað hvort ritverk eins og Laxdœela sé á einhvern hátt sérstaklega ákjósanlegt sem tæki til að pjálfa gagnrýna hugsun 1 grunnskóla. Á pessu máli eru tvær hliðar sem verður að huga sérstaklega að. Önnur hliðin er heimspekileg og varðar sjálfa hugmyndina um gagnrýna hugsun; hvað hún er og hvernig mætti kenna hana. Hin er verkleg og lýtur að veruleika skólans sem parf að sinna ótal viðfangsefnum á sama tíma, er pegar ofhlaðinn verkefnum, hefur úr takmörkuðum námsgögnum að moða, býr við mjög stýrt skipulag aðalnámskrár og stundatöflu, hefur yfir að ráða kennurum sem hafa ekki endilega pælt mikið í pví hvað gagnrýnin hugsun er en eru hins vegar sérfræðingar í ótal öðrum hlutum.

Ég byrja á að fjalla stuttlega um heimspekilegu spurninguna - í hverju gagnrýnin hugsun er fólgin (2. hluti) og hvernig mætti kenna eða pjálfa hana (3. hluti). Hin heimspekilega umfjöllun leggur til forsendur fyrir umfjöllun um hvort og pá hvaða sérstöðu Laxdola hafi í pessu tilliti (4. hluti) en um pað efni fjalla Atli Harðarson og Róbert Jack í sínum greinum í pessu sérhefti Netlu. Í framhaldinu fjalla ég svo nánar um hina verklegu hlið (5. hluti), p.e. pá hlið sem lýtur að starfi í skólum, sem einnig er viðfangsefni Póru Bjargar Sigurðardóttur í pessu sérhefti Netlu. Umfjöllun mín í pessari grein byggist að hluta til á rannsóknarverkefni par sem unnið var með Laxdælu sem kennsluefni í íslensku á unglingastigi í prem grunnskólum. Rannsóknarverkefninu er nánar lýst í greininni „Laxdaela saga og siðferðilegt uppeldi í skólum“ í pessu sérhefti Netlu.

\section{Gagnrýnin hugsun}

Víkjum fyrst að hinni heimspekilegu hlið málsins, p.e. hvað gagnrýnin hugsun sé og hvað í pví felist að kenna eða pjálfa slíka hugsun. Umfjöllun um petta efni á íslensku á sér nokkuð langa sögu. Segja má að Porsteinn Gylfason hafi vakið máls á pví í árdaga akademískrar heimspeki á Íslandi í greininni „Að hugsa á íslensku“ sem birtist fyrst í Skírni árið 1972. Páll Skúlason setti gagnrýna hugsun síðan rækilega á dagskrá með útvarpserindum árið 1987 sem báru yfirskriftina „Er hægt að kenna gagnrýna hugsun?“ og voru prentuð í Pælingum sama ár (Páll Skúlason, 1987). Segja má að upp frá pessu hafi próast íslensk hefð par sem fjallað hefur verið um gagnrýna hugsun ekki einungis sem pekkingarfræðilegt og rökfræðilegt viðfangsefni heldur einnig sem siðfræðilegt viðfangsefni, eins og Henry Alexander Henrysson og Páll Skúlason gera að umræðuefni í nokkrum greinum á vefnum „Gagnrýnin hugsun og siðfræði“ (2015) og í lengra máli í bókinni Hugleiðingar um gagnrýna hugsun (Henry Alexander Henrysson og Páll Skúlason, 2014). Í greininni „Gagnrýnar manneskjur“ (Ólafur Páll Jónsson, 2008) og í bókinni Sannfæring og rök (Ólafur Páll Jónsson, 2016) geng ég jafnvel lengra en Henry Alexander og Páll með pví að líta svo á að раð að vera gagnrýninn varði ekki einungis hugsun manns heldur nái einnig yfir skynjun manns og færni manns til að breyta í samræmi við eigin gildi og hugsun. Í pví sem hér fer á eftir mun ég halda mig innan pessarar hefðar og líta á gagnrýni eða gagnrýna hugsun sem víðan eiginleika sem nær yfir pekkingarfræðilega, siðferðilega, verklega og fagurfræðilega eiginleika manneskjunnar.

Pótt gagnrýnin hugsun, í pessum íslenska skilningi, sé augljóslega ekki pröngt tæknilegt viðfangsefni (eins og „critical thinking“ birtist stundum í bandarískum kennslubókum) heldur víðtækt viðfangsefni sem varðar ólíkar hliðar manneskjunnar, pá segir petta okkur ekki mikið um hvað pað nákvæmlega pýði að manneskja sé gagnrýnin eða hvernig megi yfirleitt skilgreina gagnrýna hugsun. Guðmundur Heiðar Frímannsson (2018) gerir greinarmun á prennskonar kenningum um gagnrýna hugsun sem hann kallar: 


\section{(1) Ferlakenningar}

(2) Skrefa- eða prepakenningar

(3) Færnikenningar

Til að átta sig á flækjunum við að segja til um hvað gagnrýnin hugsun er - eða hvers vegna pað er ekki hægt með góðu móti - og hvað purfi að hafa í huga til að kenna hana er gagnlegt að skoða pessar prennskonar kenningar.

Ferlakenningar um gagnrýna hugsun gera ráo fyrir pví að hugsun sem sé gagnrýnin eigi sér stað fyrir tilverknað ákveðins ferlis í huga fólks. Dæmi um ferli sem e.t.v. mætti bera saman við gagnrýna hugsun er melting. Í bókinni Explaining Behavior notar bandaríski heimspekingurinn Fred Dretske (1991) einmitt meltingu sem dæmi til að skýra hvað hann á við með ferli. Dretske skiptir meltingarferlinu niður í prjú stig á eftirfarandi hátt.

\begin{tabular}{c|l|l}
1 & \multicolumn{1}{c|}{2} & \multicolumn{1}{c}{3} \\
\hline $\begin{array}{l}\text { Matur er innbyrtur og honum } \\
\text { blandað við meltingarvökva. }\end{array}$ & $\begin{array}{l}\text { Ýmis ensím fara að } \\
\text { vinna á matnum. }\end{array}$ & $\begin{array}{l}\text { Maturinn er brotinn } \\
\text { niður í einföld efnasambönd. }\end{array}$
\end{tabular}

Melting er ekki tiltekinn atburður, kringumstæður eða ástand sem veldur pví að mat er breytt í einföld efnasambönd, heldur er meltingin röð atburða og tiltekin afleiðing peirra. Til að átta sig á pví hvort melting hafi átt sér stað, pá parf að átta sig á pví hvort meltingarferlið hafi átt sér stað, bæði atburðirnir og niðurstaðan. Hugmyndin um að gagnrýnin hugsun sé hugarferli er pá sú að hún sé á einhvern hátt sambærileg við líkamsferli eins og meltingu; gert er ráð fyrir að gagnrýnin hugsun - og kannski almennt pað sem kalla mætti góða hugsun - samanstandi af tiltekinni tegund atburða (hugsana) auk niðurstöðu (afstöðu, skoðunar, staðhæfingar, sannfæringar).

Guðmundur Heiðar færir sannfærandi rök gegn ferlakenningu um gagnrýna hugsun. Í hnotskurn eru rök hans pau að ef gagnrýnin hugsun væri ferli í pessum skilningi pá væri sjaldnast nokkur leið að meta hvort tiltekin hugsun hefði verið gagnrýnin eða ekki par sem ferlin séu okkur yfirleitt algerlega hulin. Við verðum ekki vitni að neinum hugarferlum pegar aðrir hugsa, hvort sem hugsunin er gagnrýnin eða ógagnrýnin, og við höfum sjaldnast aðgang að pessum ferlum í okkar eigin hugsun. Vel má vera að hugsun sé ferli - eins og hegðun okkar er ferli, atferli - en pegar við lýsum tiltekinni hugsun sem gagnrýninni pá er pað ekki á grundvelli pess að við höfum orðið vitni að tilteknu hugarferli. Dar fyrir utan, pá pyrftum við fyrst að vita hvað gagnrýnin hugsun væri til að geta sagt til um hvaða ferli væru ferli gagnrýninnar hugsunar.

Líta má á skrefa- eða prepakenningar sem tilraun til að bregðast við göllunum á ferlakenningunum. Hugmyndin er pá sú að pað sem einkennir gagnrýna hugsun - eða pað sem gerir hugsun gagnrýna frekar en ógagnrýna - sé að hún fylgi tilteknum skrefum. Skrefin birtast pá væntanlega sem áfangar í hugsuninni og eru að öllu jöfnu sýnileg. Og pegar pau eru ekki sýnileg, mætti gera pau sýnileg með pví að spyrja spurninga; spyrja hugsuðinn hvað hann sé að gera, hvernig hann hafi komist að tiltekinni niðurstöðu og hvers vegna. Hér mætti pá e.t.v. tala um aðferðafræði gagnrýninnar hugsunar. Sem möguleg dæmi um skref eða prep gagnrýninnar hugsunar nefnir Guðmundur Heiðar eftirfarandi:

... аð [1] skilgreina vandann, [2] rannsaka mögulegar lausnir, [3] velta fyrir sér afleiðingunum, [4] athuga mikilvægi afleiðinganna, [5] ákveða hvað á að gera, [6] meta markmið. Síðan pyrfti að brjóta hvern pennan pátt niður í smærri atriði og fylgja peim nokkuð nákvæmlega. (Guðmundur Heiðar Frímannsson, 2018, bls. 131 (tölusetning ÓPJ)) 
Eins og Guðmundur Heiðar bendir á er einn vandinn við pessa hugmynd að hún leggur ekki til nein nauðsynleg eða nægjanleg skilyrði fyrir pví að hugsunin sem á sér stað sé gagnrýnin. Vandinn blasir raunar við í hverju skrefi. Tökum skref (2) sem dæmi, að rannsaka mögulegar lausnir. Á flestum vandamálum má hugsa sér ótölulegan fjölda lausna, sumar góðar, aðrar slæmar, en flestar kannski einhvers staðar par á milli. Pá vaknar spurningin: Hvaða lausnir parf að rannsaka svo hugsun geti talist gagnrýnin? Við pessu er ekkert skýrt svar. Kannski er skásta svarið: „Đær lausnir sem skipta máli“ eða „Dær lausnir sem koma til greina“. En enginn getur sagt fyrirfram neitt um раð hvaða lausnir skipta máli eða koma til greina. Og svo getur væntanlega vel verið að maður hafi hugsað gagnrýnið um tiltekið vandamál en samt yfirsést lausnir sem skipta máli og koma til greina, jafnvel pær bestu.

Vandinn við að skilgreina gagnrýna hugsun sem röð af prepum eða skrefum bendir okkur á atriði sem alltaf var kannski ljóst, pótt pað fengi ekki næga athygli: Að hugsa gagnrýnið varðar í senn aðferðir, aðgerðir og innihald. Að fylgja aðferð og framkvæma tilteknar aðgerðir - t.d. eins og í skrefunum sex hér að framan - tryggir ekki innihald. Innihaldið varðar m.a. atriði eins og að taka réttmatt tillit til aðstæðna, meta með sanngjörnum hætti pað sem bent er á, taka hafilegt tillit til gagnrýni, leita álits hjá peim sem eru líklegir til að hafa vit á málinu, o.s.frv. Allir pessir pættir eru matskenndir og næmir fyrir kringumstæðum og pví verða peir ekki skilgreindir með formlegum hætti. Af pessu leiðir að kennsla í gagnrýninni hugsun getur ekki verið einfaldlega pjálfun í tilteknum aðferðum eða aðgerðum, pótt hún innifeli slíka pjálfun. Vandinn hér er sá sem Porsteinn Gylfason orðaði ágæetlega í greininni „Að hugsa á íslenzku“:

... tóm tækni hefur pann umtalsverða kost að hana má kenna, oft með ágætum árangri. Рað má kenna mönnum að beita reglum við að greina stuðla og höfuðstafi, orðflokka og setningarhluta, en engum hefur tekizt svo ég viti að kenna manni að yrkja gott kvæði. Eins má kenna rökfræði og stærðfræði, en gott vald manns á pessum greinum, á reikningstækni peirra, er engin trygging fyrir viturlegri eða frumlegri hugsun. Баð er ekki einu sinni trygging fyrir almennri heilbrigðri skynsemi. (Dorsteinn Gylfason, 1996, bls. 34-35)

Ef við gefum upp á bátinn pá von að skilgreina megi gagnrýna hugsun sem einhverskonar röð aðgerða, hvað er pá eftir? Af listanum sem Guðmundur Heiðar lagði til er einungis sú hugmynd eftir að gagnrýnin hugsun sé færni, eða öllu heldur, аð раð аð hugsa gagnrýnið sé til marks um að viðkomandi hugsuður búi yfir tiltekinni færni.

Sé litið á gagnrýna hugsun sem færni - og pá pað verkefni að kenna gagnrýna hugsun sem pað að kenna eða pjálfa slíka færni - pá parf aftur að spyrja: Hvaða færni? Í hverju er slík færni fólgin? Hvað inniber hún? Ef við lítum í dæmigerða kennslubók í gagnrýninni hugsun mætti ætla að slík færni væri einkum fólgin í getu til að draga rökréttar ályktanir, koma auga á rökvillur eða aðra annmarka á skoðanamyndun, geta skýrt merkingu hugtaka, og fleira í peim dúr (sbr. Ólaf Pál Jónsson, 2016, fyrsta og annan hluta). Hér hvílir punginn gjarnan á pví að læra formlegar eða hálfformlegar aðgerðir enda kannski ekki öðru til að dreifa í bók sem á að vera kennslubók. Slíka færni má kenna og hún er örugglega gagnleg. En pað eitt að ná tökum á tækninni er langt frá pví að vera nokkur trygging fyrir viturlegri eða frumlegri hugsun, eins og Dorsteinn benti á fyrir löngu. Í greininni „Skynsemi eða rökleikni“ rekur Eyja Margrét Brynjarsdóttir (2013) ágæett en grátbroslegt dæmi par sem hin tæknilega færni virðist vera til staðar en hugsunin síður en svo gagnrýnin. Hún segir par frá dönskum rökfræðiprófessor sem tók upp á pví að auglýsa námskeið 1 rökfræði með myndum af sér par sem hann stillti sér upp í hópi fríðra en fáklæddra kvenna. Prófessorinn hafði eflaust ágætt vald á rökfræði, gat komið auga á rökvillur eins og pær að játa baklið eða neita forlið, og fleira í peim dúr. Hins vegar blasir við að uppátækið allt einkenndist af átakanlegum skorti á gagnrýninni hugsun. Málið er, eins og Eyja Margrét og fleiri hafa bent á, að gagnrýnin hugsun er miklu víðara hugtak. Eyja Margrét orðar pað svo að hún sé vönduð hugsun sem stuðli að sanngjörnum og opnum skoðanaskiptum (2013, bls. 74). 
Spurningunni um hvers konar færni gagnrýnin hugsun sé er enn ósvarað. Færnin er raunar mjög margvísleg og tekur bæði til tæknilegra atriða, eins og að geta skilgreint vanda (sbr. atriði (1) í tilvitnuninni að framan), verklegra atriða eins og að geta ákveðið hvað á að gera og gera раð svo (sbr. atriði (5) í tilvitnuninni að framan), en einnig siðferðilegrar færni eins og að meta hvað séu verðug viðfangsefni, hvað skipti siðferðilega máli, hvaða lausnir séu ýmist tækar eða ekki tækar af siðferðilegum ástæðum, og ekki síst samskiptafærni pví gagnrýnin hugsun krefst næmni á margvísleg sjónarmið og að geta hugsað í samfélagi við aðra (sbr. Henry Alexander Henrysson, 2013; Ólaf Pál Jónsson, 2016, 7. kafla). Góð gagnrýnin manneskja hlýtur pví að búa yfir (i) tæknilegri færni (e. skill), til dæmis að geta dregið rökréttar ályktanir, og (ii) tilteknum vitsmunadygðum (e. intellectual virtues), eins og forvitni og hyggindum eða frónesis sem var höfuðdygð í siðfræði Aristótelesar. Manneskja sem býr yfir peirri færni sem einkennir gagnrýninn hugsuð í víðum skilningi býr einnig yfir (iii) tilteknum siðferðisdygðum (e. moral virtues) eins og sanngirni og heiðarleika - pað krefst heiðarleika og hreinskilni gagnvart sjálfum sér og öðrum að skipta um skoðun pegar rökin hníga að endingu í pá áttina. Hin gagnrýna manneskja parf einnig að búa yfir (iv) verknaðardygðum (e. performance virtues) eins og seiglu og polinmæði - oft parf heilmikla seiglu til að finna og próa rök fyrir afstöðu sem maður er innst inni sannfærður um.

\section{Að kenna gagnrýna hugsun}

Ef við föllumst á að gagnrýnin hugsun krefjist færni og margvíslegra dygða, bæði vitsmunadygða, siðferðisdygða og verknaðardygða, pá hljótum við líka að fallast á að kennsla eða pjálfun í gagnrýninni hugsun falli innan pess sem kallað hefur verið skapgerðarmenntun eða mannkostamenntun (e. character education). Í slíkri menntun er megináherslan gjarnan lögð á tilteknar dygðir eins og rakið er í greininni „Laxdæla saga og siðferðilegt uppeldi í skólum“ í pessu sérriti. Í staðinn fyrir að spyrja hvort Laxdæla sé heppileg til að kenna gagnrýna hugsun í grunnskóla gætum við pví spurt hvort sagan sé heppileg fyrir mannkostamenntun á pví skólastigi. Með pessu geri ég ekki ráð fyrir að kennslu í gagnrýninni hugsun megi leggja að jöfnu við mannkostamenntun. Pótt mannkostamenntun feli í sér kennslu og pjálfun í dygðum sem varða gagnrýna hugsun er mannkostamenntun víðara hugtak en kennsla í gagnrýninni hugsun.

Í inngangi að bókinni Teaching Character Education Through Literature segir Karen E. Bohlin að mannkostamenntun hafi fengið vind í seglin við upphaf 10. áratugar 20. aldar og pegar bók hennar kom út árið 2005 segir hún ,að mannkostamenntun sé enn á ný mikilvægt viðfangsefni og að leiðirnar sem ólíkir fræðimenn, kennarar, stjórnmálamenn og stefnumótendur aðhyllist séu jafn ríkulegar, fjölskrúðugar og umdeildar og pær eru margar“ (Bohlin, 2005, bls. 1). Bohlin greinir síðan fernskonar hugmyndafræði sem liggi mannkostamenntun í Bandaríkjunum til grundvallar. Í fyrsta lagi séu verkefni sem eigi ræur í hugmyndum Johns Dewey, Lawrence Kohlberg og fleiri. Slíkar hugmyndir hafi m.a. verið próaðar af bandaríska heimspekingnum Nel Noddings (1992, 2002). Í öðru lagi nefnir Bohlin verkefni sem tengist pví að nemendur geri sér grein fyrir eigin gildum (e. values clarification) frekar en eiginlegri kennslu í siðferði. Í priðja lagi séu sjónarmið sem byggist á félags- og tilfinningalegu námi (e. social and emotional learning) par sem lögð sé áhersla á margvíslega færni eða hæfni á breiðu sviði, allt frá pví að kunna skil á öruggu kynlífi yfir í að forðast vímuefni. Í fjórða lagi séu svo verkefni sem byggist á hefð dygðasiðfræði (t.d. Arthur, 2003). Um pessa fernskonar hugmyndafræði segir Bohlin svo:

Pótt allar pessar leiðir miði að pví að stuðla að siðferðilegum proska pá missa margar peirra marks. Pótt fyrstu prjár leiðirnar leggi til ýmis gagnleg sjónarmið pá duga pær ekki pegar kemur að pví að kenna unglingum hvernig megi koma auga á hvað sé farsælt líf og hvers vegna pað sé eftirsóknarvert. Pær duga ekki vegna pess að pær leggja ekki til nein sannfærandi rök fyrir pví að lifa góðu lífi. Skorti skilning á pví hvað pað pýði fyrir manneskju að lifa á virðingarverðan hátt, er getan til siðferðilegrar umhugsunar algerlega stefnulaus. Án skilnings á pví hvað sé siðferðilega gott og eftirsóknarvert er sú iðja að skýra fyrir sér sín eigin gildi innantóm (Bohlin, 2005, bls. 3). 
Mannkostamenntun síðasta áratuginn eða svo hefur einmitt sótt í ríkum mæli í dygðasiðfræði sem fræðilegan grunn (sbr. Carr og Harrison, 2015; Arthur, Kristjánsson, Harrison, Sanderse og Wright, 2017). Stundum hafa fræðimenn pó e.t.v. afskrifað að ósekju annarskonar siðfræðilegar forsendur, t.d. skyldusiðfræði í anda Immanuels Kant, eins og rakið er 1 fyrstu grein pessa sérrits. Dað skiptir máli í pessu sambandi að áhersla á dygðir sem viðfangsefni í kennslu, par sem siðferðilegur proski er meginmarkmið, parf ekki að byggjast á dygðasiðfræði. Vel má rökstyðja áherslu á dygðir sem viðfangsefni í kennslu og skilning á dygðaorðaforða sem mikilvægt markmið mannskostamenntunar út frá skyldusiðfræði og jafnvel ýmsum útgáfum af nytjastefnu.

Sé litið á kennslu í gagnrýninni hugsun sem mannkostamenntun og séu dygðirnar sem leggja til uppistöðu mannkostanna skildar aristótelískum skilningi, pá er ljóst að kennsla í gagnrýninni hugsun er víðtækt viðfangsefni sem tekur í senn til pekkingarmarkmiða námsins, siðferðilegra eiginleika nemendanna, tilfinningalegrar afstöðu peirra og verklegrar færni.

\section{Laxdæla og mannkostamenntun í grunnskóla}

En hvers vegna að vera að velta nemendum upp úr Laxdælu ef markmiðið er mannkostamenntun? Er sú saga vel til pess fallin að pjálfa nemendur á grunnskólaaldrií dygðum? Og hafa fornbókmenntir einhverja kosti fram yfir aðrar bókmenntir? Til að svara pessum spurningum parf að huga að hinni verklegu hlið viðfangsefnisins - frekar en peirri heimspekilegu. Byrjum á nokkrum einföldum atriðum sem pó skipta verulegu máli.

Laxdæla er engin dægurfluga heldur saga sem hefur verið lesin í skólum í fjölmörg ár og er líkleg til að halda peirri stöðu a.m.k. í náinni framtíð. Sagan er, með öðrum orðum, klassísk; hún hefur staðið af sér dægursveiflur í smekk og efnisvali. Detta pýðir að auðvelt er að taka söguna til umfjöllunar - p.e. gera hana að námsefni skóla - án pess að purfa par með að leggja eitthvað nýtt inn í skólastarfið. Einnig er raunhæft að undirbúa kennslu, búa til stuðningsefni og fleira, án pess að eiga á hættu að efnið úreldist á skömmum tíma (sjá t.d. nýja útgáfu Menntamálastofnunar á Laxdælu (Gunnar Karlsson, 2017) og vefinn islendingasogur.is/laxdaela/). Auk pess eru skólarnir líklegir til að eiga bekkjarsett af bókinni, kennararnir kannast við söguna, einhver reynsla er komin á pað hvaða aldurshópur ræður við söguna (í einfaldaðri útgáfu), o.s.frv. Detta eru kostir sem Laxdcla hefur umfram margar aðrar bækur.

En hvað með söguna sjálfa, inntak hennar, atburðarás, persónusköpun og fleira? Hér vakna strax ýmis álitamál sem ekki er alveg einfalt að leysa úr. Eitt er að pað er hreint ekki ljóst hvert sé inntak sögunnar; hver sé kjarninn í henni, ef hann er pá einhver. Til pess að eiga einhverja von á að ná tengingu við söguna parf að leita að kjarna hennar, reyna að átta sig á peim málefnum - en ekki bara sögupræði - sem sagan hverfist um. Er petta saga um ást í meinum? Er petta saga Guðrúnar Ósvífursdóttur, sem fyrst er gift barn að aldri, á seinna meir í ástarsambandi við mesta glæsimenni Íslands en verður síðan völd að dauða hans (sbr. Auerbach, 1998; Helgu Kress, 1980)? Auerbach bendir á að Guðrúnu sé lýst sem jafningja Kjartans en að hörmungarnar byrji pegar Kjartan fer til Noregs, neitar Guðrúnu um að koma með og pvingar hana til að taka upp hefðbundið kvenhlutverk sem einkennist af undirgefni og pjónustu (Auerbach, 1998, bls. 30). Eða er petta harmsaga Bolla sem hlýtur pau örlög að verða bani fóstbróður síns (sbr. grein Atla Harðarson (2018) í pessu sérhefti Netlu)? Er petta kannski ættarsaga afkomenda Unnar djúpúðgu par sem engin ein persóna er í brennidepli? Í fyrstu mætti ætla að pessi margræðni Laxdælu sé ókostur sem geri hana beinlínis að óheppilegu námsefni fyrir unglingastig grunnskóla eða framhaldsskóla. Ég hygg pó að einmitt pessi margræðni sögunnar sé kostur frekar en galli, eins og ég mun nú reyna að útskýra.

Aðrar fornsögur, svo sem Gísla saga, Grettis saga og Njáls saga, hafa marga sömu kosti og Laxdcela fyrir mannkostamenntun á unglingastigi í grunnskóla eða í framhaldsskóla. Að einu leyti virðist mér pó að Laxdœla sé heppilegri en bæði Gísla saga og Grettis saga (pær kunna vitaskuld að hafa aðra kosti sem Laxdælu skortir). Margræðni Laxdælu kallar á rökræðu um hver sé aðalpersóna 
sögunnar og um hvað sagan eiginlega sé. Sagan er spennandi og ótrúlega vel skrifuð, svo vel аð höfundinum - eða höfundunum - hefur tekist að skilja lesandann eftir með pessar stóru spurningar. Í Grettis sögu og Gísla sögu er alveg ljóst hver aðalpersónan er, nefnilega Grettir og Gísli. Hápunktur Laxdælu er augljóslega pegar Bolli vegur Kjartan. En pótt petta sé hápunkturinn, og pótt Kjartan og Bolli séu báđir mikilsverðar persónur í sögunni - kannski aðalpersónur hennar - pá er bróðurpartur sögunnar um aðra en pá tvo og margir mikilvægir atburðir eiga sér stað eftir að peir eru báðir horfnir af sögusviðinu. Hér er einn meginkostur Laxdælu sá að sagan leggur spurningar fyrir lesendur en svarar peim ekki. Hún býður upp á margar túlkanir sem hægt er að rökstyðja og er pví heppilegt efni í opna umræðu par sem hægt er að taka ólíkan skilning nemenda alvarlega.

Hvaða leið sem lesandinn fer í gegnum Laxdælu, pá fer tæpast framhjá honum að sagan fjallar um málefni sem brenna á ungmennum sem eru að ljúka grunnskóla eða byrja í framhaldsskóla. Hún fjallar um vináttu, trúmennsku, heiðarleika, sáttfýsi og samskipti, svo eitthvað sé nefnt. Og vitaskuld líka um hatur, sviksemi, lygar og blekkingar, óheiðarleika, heift og hefnigirni. Með pví að hafa pessar dygðir og pessa lesti í forgrunni pegar sagan er lesin - og vinna skipulega með merkingu peirra og mikilvægi - pá opnast sagan fyrir ungmennum sem láta jafnvel pau orð falla að hún sé nútímaleg (viðtal við rýnihóp, 28.10.2017).

Dær dygðir og peir lestir sem Laxdœla hverfist um skipta máli í lífi ungmennanna sjálfra. Hins vegar kemur í ljós pegar ungmenni eru spurð út í siðferðilegan orðaforða, orð eins og „,prautseigja“, „hógværð“, „,heift“ og „sáttfýsi“, að mörg peirra pekkja ekki orðin (sjá grein Póru Bjargar Sigurðardóttur (2018) í pessu sérhefti Netlu). Vitaskuld eru eiginleikarnir eða dygðirnar sem pessi orð vísa til börnunum ekki framandi - ekki alveg að minnsta kosti - en orðin eru peim ekki töm, sem aftur pýðir að pau eiga erfitt með аð ræða um pessa eiginleika eða dygðir. Меð pví að taka tilteknar dygðir skipulega fyrir pegar sagan er lesin pá gerist í raun tvennt. Annars vegar opnast sagan fyrir unglingunum sem verðug og spennandi, og hins vegar eflist orðaforði peirra og leikni í að rökræða um dygðir og lesti. Rökræða um inntak sögunnar verður rökræða um siðferðilega eiginleika sögupersónanna.

Einhver gæeti spurt hvort um pær dygðir og pá lesti sem sögupersónurnar í Laxdælu sýna megi ekki allt eins lesa í samtímaskáldskap sem standi unglingunum nær en saga úr grárri forneskju. Dví mætti jafnvel halda fram að fornsögurnar séu óheppilegar til að fjalla um siðferði pví hæpið sé að leggja sama skilning í siðferðileg hugtök Laxdælu og pau sem notuð eru í samtímanum. Hér kemur bæði til að málfar Laxdælu er nokkuð frábrugðið nútímamáli pannig að til að finna algengum dygðum stað í sögunni parf nokkra túlkun (sbr. greinar Róberts Jack (2018a, 2018b) 1 pessu sérhefti Netlu). Og svo er sá félagslegi og siðferðilegi jarðvegur sem sagan er sprottin úr allt annar en sá sem við pekkjum í dag. Athugasemdin er í hnotskurn pessi: Samtímaskáldskapur er jafn ríkur af siðferðilegum álitamálum og fornsögurnar en hefur pað umfram pær að ekki parf að brúa langt bil í málfari, sögu og menningu. Vissulega er petta ákveðinn kostur við samtímaskáldskap, en um leið getur petta atriði einnig talist fornsögunum til tekna. Fjarlægð sögusviðs er ekki endilega galli pví pegar um er að ræða siðferðileg álitamál getur of mikil nánd verið erfið og jafnvel útilokað sanngjörn og opin skoðanaskipti. Fjarlægð sögusviðsins getur auðveldað umræðu um viðkvæm mál vegna pess að umræðan fjallar ekki um pá sem eru pátttakendur í peim eða snerta pá með beinum hætti. Nemendur í grunnskóla geta hæglega rætt um trúmennsku, prautseigju og blekkingar, sáttfýsi og hefnigirni sögupersónanna í Laxdælu án pess að peirra eigin tengsl og samskipti flækist fyrir. Sagan gefur líka tilefni til að ræða efni eins og mansal, flóttamenn, refsingar, fordóma í garð fólks af öðrum uppruna, stéttaskiptingu og fleira sem varðar siðferði samfélags ekki síður en dygðir og lesti einstaklinga án pess að höggvið sé nærri einstökum nemendum. Pótt sögusvið álitamála sem pessara sé í nokkurri fjarlægð, hvort heldur um er að ræða hin einstaklingsbundnu eða samfélagslegu álitamál, kemur petta ekki í veg fyrir að nemendur yfirfæri pað sem gerist í sögunni yfir á sitt eigið líf; ef slík yfirfærsla væri ómöguleg myndu pau ekki lýsa sögunni sem „nútímalegri“ eins og pau samt gera. 
Fjarlægð sögusviðsins hjálpar líka til með öðrum hætti. Vegna pess að ýmislegt er framandi í sögunni, bæði í efnislegu umhverfi hennar og í siðferðilegum og lagalegum veruleika, sem og í orðanotkun, pá krefst sagan pess af lesendum að peir spyrji spurninga sem peir eru ekki endilega vanir að spyrja um sinn eigin samtíma - umhverfi, venjur, menningu, tungumál o.fl. Segja má að sagan sé hæfilega framandi til að krefjast samræðna um atburði, sögusvið og, ekki síst, gildismat og orðaforða. Loks er fjarlægð sögusviðsins til pess fallin að brúa bil á milli barna og ungmenna af erlendum uppruna og peirra sem eiga allar sínar ræetur í íslenskum veruleika. Saga úr íslenskum samtíma er aðgengilegri peim sem eiga rætur innanlands en t.d. börnum pólskra innflytjenda. Laxdela er aftur á móti álíka aðgengileg hvorum tveggja - og svo hefur hún verið pýdd á mörg tungumál, sem skiptir t.d. máli í framhaldsskóla ef nemandi á auðveldara með að lesa annað mál en íslensku.

Dótt flestar skáldsögur kalli á túlkun má ætla að eftir pví sem framandleiki sögusviðsins er meiri pví róttækari verði túlkunarspurningarnar sem vakna við lesturinn. Við getum gert greinarmun á afmörkuðum túlkunarspurningum annars vegar, par sem túlkun lýtur forsendum og kringumstæðum sem eru nokkuð vel pekktar, og róttækum túlkunarspurningum hins vegar, par sem slíkur rammi er ekki ljós heldur kallar sjálfur á túlkun. Skilin parna á milli eru vitanlega ekki skýr en pegar um er að ræða kennslu í gagnrýninni hugsun má ætla að róttækar túlkunarspurningar risti að jafnaði dýpra en hinar afmörkuðu. Ágætt dæmi um petta er atburðurinn pegar Kjartan fer með lið að Laugum í Sælingsdal, par sem Guðrún Ósvífursdóttir og Bolli búa, og dreitti pau inni í prjá daga, p.e. lokaði húsunum pannig að fólk komst ekki út til að ganga örna sinna. Um eftirmál pessa segir svo:

Deim Laugamönnum líkar illa og pótti petta miklu meiri svívirðing og verri en pótt Kjartan hefði drepið mann eða tvo fyrir peim. Voru peir synir Ósvífurs óðastir á petta mál en Bolli svafði heldur. Guðrún talaði hér fæst um en pó fundu menn pað á orðum hennar að eigi væri víst hvort öðrum lægi í meira rúmi en henni. Gerist nú fullkominn fjandskapur milli Laugamanna og Hjarðhyltinga. (Laxdæla, 47. kafli)

Ljóst er að pessi atburður markar páttaskil í samskiptum Kjartans, annars vegar, og Guðrúnar og Bolla, hins vegar. En af hverju? Hvers vegna var petta svona alvarlegt? Hvers vegna er verra að komast ekki á salerni í prjá daga en ef maður eða tveir hefðu verið drepnir? Spurningum sem pessum er engin leið að svara öðruvísi en að taka til skoðunar gildi og venjur, velta fyrir sér mikilvægi sæmdar, á hverju hún sé byggð og hvað geti valdið sæmdarmissi. Hér vakna einnig spurningar um gildi lífs og svo vitaskuld spurningar, sem væntanlega eru nærtækar í lífi ungmennanna sjálfra, um pað hvað ást og afbrýðisemi geta leitt manneskjur út í.

Af pessum sökum geta fornsögur verið heppilegra kennsluefni en sögur úr samtímanum enda krefjast pær pess að lesendur setji sig í aðrar stellingar og skoði siðferðileg álitamál út frá annars konar viðmiðum en peir eiga að venjast. Hið sama gæti einnig átt við um sögur úr fjarlægum heimshornum. Fjarlægðin gerir ekki bara fjöllin blá, hún krefst líka dýpri pælinga.

\section{Lokað safn staðreynda eða opið tilboð um samræður}

Markmiðið með pví að lesa Laxdælu með gleraugum dygðasiðfræðinnar er tvennskonar. Annars vegar að opna bókina fyrir nemendum sem áhugaverða sögu sem hægt er að sökkva sér í og gefur tilefni til að ræða um persónugerð, samskipti, tengsl, dygðir, lesti og fleira. Hér er heimspekin tæki til að komast inn í söguna, til að ná tengingu við efnið og örva pað ímyndunarafl sem skapandi lestur krefst. Hins vegar að nota söguna til að pæla í siðferðilegum hugtökum, gildum og jafnvel kenningum. Hér er sagan í raun tæki til að örva siðferðilegt ímyndunarafl og kveikja samræður um siðferðileg efni.

Að nálgast efnið með pessum hætti er í góðu samræmi við pað sem Karen Bohlin segir í áðurnefndri bók sinni, Teaching Character Education Through Literature. Bókin er byggð á reynslu 
Bohlin sjálfrar af bókmenntakennslu og heimspekilegum og bókmenntafræðilegum pælingum í tengslum við slíka kennslu. Framarlega í bókinni lýsir Bohlin pví sem fyrir henni vakir:

Áhugi minn er ekki einfaldlega bókmenntirnar sjálfar, sem Kafka sagði svo rausnarlega að byggju yfir mætti til að „,píða hið ísilagða haf innra með okkur“. Spurningar mínar eru frekar ætlaðar til pess að hjálpa bókmenntakennurum að skapa pann hita, ef svo má segja, sem parf til að koma pessu píðingarferli af stað. (Bohlin, 2005, bls. 6)

Litlu síðar skýrir Bohlin nánar hvað hún á við með pessum orðum. Hún lýsir pví sem margir bókmenntakennarar kannast eflaust við.

Fyrir tiltekna nemendur getur pað að lesa skáldsögu breyst í kvöð, eða í skásta falli illa nauðsyn. Deir skauta yfir yfirborð textans og leita að atriðum sem peir halda að verði spurt um á prófi eða að nokkrum vænlegum tilvitnunum sem nota má í ritgerð sem pá varðar annars lítið um. Aðrir leggja sig fram um að fella lestur sögunnar inn í bókmenntagreiningu um táknmynd, kaldhæðni eða frásagnarhátt. Fáir ungir lesendur bókmennta taka raunverulega tíma í að hugleiða hvað gerist og hvers vegna. Og af pessum sökum missa margir lesendur af tækifærinu til að sjá hvað mótar siðferðilega próun peirra persóna sem peir eru að lesa um. Deir purfa hjálp við að kryfja merkingu. (Bohlin, 2005, bls. 7)

Í rannsóknarverkefni með nokkrum kennurum par sem dygðahugtök voru skipulega notuð til að kryfja Laxdælu má sjá breytingar í pá átt sem Bohlin kallar eftir. Degar kennarar báru lesturinn á Laxdælu saman við fyrri kennslu á öðrum Íslendingasögum, ekki síst eldri kennararnir sem höfðu kennt Gísla sögu til samræmdra prófa, kom fram að hin siðferðilega nálgun opnaði söguna og skapaði samræðuvettvang um hluti sem skiptu nemendurna máli. Degar Íslendingasögur höfðu verið kenndar til samræmds prófs - en líka pegar styttri saga eins og Hrafnkels saga Freysgoða hafði verið lesin með áherslu á sögupráð - birtist sagan sem safn lokaðra staðreynda. Nemendur lásu kannski sögurnar en höfðu enga sérstaka skoðun á peim (sjá Dóru Björgu Sigurðardóttur, 2018). Sögurnar voru eins og hvert annað staðreyndasafn sem mátti leggja á minnið en gleyma svo um leið og önnin var liðin.

Vandinn hér er vel kunnur meðal peirra sem kenna Íslendingasögur, eins og Rósa Marta Guðnadóttir víkur að í meistararitgerð sinni, og vitnar til orða Ármanns Jakobssonar:

Vandasamt getur verið að miðla efninu til nemenda á pann hátt að peir fyllist áhuga og eldmóði sem sennilega er draumur hvers kennara.Ármann Jakobsson telur pað vanda við að kenna fornsögur hve auðvelt sé að týna sér í nöfnum, staðháttum og ættartengslum. „Баð parf líka að finna í peim pá sammannlegu pætti sem gera að verkum að pær skírskota stöðugt til nýrra lesenda, kynslóð eftir kynslóð“ (Ármann Jakobsson, 2005, bls. 35). Рað er mikilvægur páttur kennslunnar. (Rósa Marta Guðnadóttir, 2015)

Ef markmiðið með lestri skáldsagna er öðrum præði að kenna nemendum gagnrýna hugsun - og gefa peim færi á að pjálfa sig í að beita slíkri hugsun bæði á valin viðfangsefni (t.d. tiltekna sögu) og á eigið líf - er augljóst að betra er að nálgast söguna sem opið tilboð um samræður um söguna og hvað eina sem hún gefur tilefni til að ræða en sem lokað safn staðreynda.

Greinarmunurinn á pessu tvennu - opnu tilboði um samræður eða lokuðu safni staðreynda - er vitaskuld ekki alltaf skýr. Hið opna tilboð er jafnan bundið tilteknum staðreyndum. Meiningin er ekki endilega að fara út fyrir söguna heldur, ef svo mætti segja, að fara dýpra inn í söguna. Ágætt dæmi um petta, en tengt annarri sögu en hér hefur verið til umræðu, eru pælingar Ármanns Jakobssonar um pað hvers vegna Pórólfur Skalla-Grímsson tekur við Agli bróður sínum og fer með hann utan til Noregs. Ármann kemst að eftirfarandi niðurstöður: 
... eina skýringin á pví að Pórólfur tekur við Agli er sú að hann búi yfir peim eiginleika sem kalla mætti hluttekningu eða innlifun (eða ampatíu á grísku en orðið er albjóðlegt og sjálfsagt að vekja athygli nemenda á pví). Pegar Pórólfur stendur frammi fyrir pessum ófrýnilega og erfiða yngri bróður sínum getur hann lifað sig inn í ömurlegt líf hans pó að hann pekki pað ekki af eigin raun. (Ármann Jakobsson, 2005, bls. 40)

Um leið og eitthvað er afgreitt sem staðreynd er fátt meira um pað að segja. Ef spurningin er t.d. hver hafi drepið Kjartan er svarið einfaldlega að pað hafi verið Bolli og málið er útrætt. En ef við spyrjum hvers vegna Bolli hafi drepið Kjartan, hvort hann hafi átt annarra kosta völ - og pá hverjir peir kostir hafi verið, hvort hann hafi heldur sýnt af sér hetjuskap eða hugleysi, o.s.frv., pá er sviðið opið fyrir umræður, ólíkar túlkanir, ólík rök.

Á líkan hátt gæetum við spurt hvort Guðrún hafi fengið að fara utan með Kjartani. Svarið liggur í augum upp, Kjartan neitaði að taka hana með. En hvaða pýðingu hafði petta, bæði beiðni Guðrúnar og neitun Kjartans? Loren Auerbach heldur pví fram að hápunktur Laxdælu sé einmitt kaflinn par sem Kjartan er á leið utan og Guðrún biður um að fara með honum. Auerbach bendir á að með pví lýsi Guðrún pví yfir að hún sé jafningi Kjartans, sem ekki aðeins hafnar beiðni hennar heldur segir henni að hún verði að vera eftir til að hugsa um föður sinn og bróður, p.e. að fara í dæmigert pjónustuhlutverk konu.

Ef saga eins og Laxdcela er lesin sem opið tilboð um samræður hefur pað áhrif á stöðu kennarans gagnvart viðfangsefninu. Annars vegar er kennarinn í stöðu sérfræðings par sem hann pekkir söguna betur en nemendurnir, hann velur einnig orð og hugtök sem notuð eru til að opna söguna, t.d. dygðahugtök eins og 1 ádurnefndu rannsóknarverkefni (sbr. greinina „Laxdæela saga og siðferðilegt uppeldi í skólum“" og greinar Róberts Jack í pessu sérhefti Netlu (2018a og 2018b)). Kennarinn stýrir einnig yfirferð og skilgreinir pau verkefni sem eru unnin. Á hinn bóginn stendur kennarinn jafnfætis nemendum par sem hann býr ekki yfir „hinni réttu túlkun“ eða ,veit hvert rétta svarið er" heldur er samstarfsmaður nemenda í peim pelingum sem sagan gefur tilefni til. Segja má að kennarinn sé hér í tvöföldu hlutverki, annars vegar sem sá sem stjórnar og býr yfir pekkingu, en hins vegar sem pátttakandi í samræðu eða rökræðu.

Degar kennsla snýst um einhliða miðlun pekkingar frá kennara til nemenda, eins og pegar litið er á viðfangsefni náms og kennslu sem lokað safn staðreynda sem nemendur purfa að tileinka sér, pá er hætt við að rökfærni nemendanna sé beinlínis skert.

Skólastarf sem einkennist af slíkri miðlun er allt eins líklegt til að kenna nemendum að aðrir viti en ekki peir, að dómar um rétt og rangt komi frá öđrum en ekki peim, að aðrir séu uppspretta pekkingar en peir sjálfir einungis viðtakendur, að aðrir séu dómbærir á hvað séu verðugar spurningar en ekki peir o.s.frv. Ef markmið skólastarfsins á að vera virkir og sjálfstæðir nemendur, sem sýna frumkvæði og reiða sig á eigin dómgreind, pá verður skólinn að finna nýjar leiðir til að miðla og skapa pekkingu og færni meðal nemenda. (Ólafur Páll Jónsson og Póra Björg Sigurðardóttir, 2012, bls. 13)

Ein leið til að komast út úr pví móti kennslu og náms sem hér er lýst er að taka skáldverk, sem kallar á róttæka túlkun og par sem enginn endir er á peim spurningum sem kunna að vakna, og nálgast pað sem opið tilboð um samræðu. Hvernig tekst til veltur síðan á bæði kennurum og nemendum. Hvorir tveggja purfa að setja sig í stellingar sem peir eru kannski ekki vanir en ef markmiðið með náminu er efling mannkosta, gagnrýnin hugsun, lýðræðislegir borgarar, pá verður tæpast undan pví vikist.

\section{Lokaorð}

Hvaða efni sem er - hvort heldur kennslubók eða skáldsaga, ljóð eða mynd - er möguleg kveikja аð samræðu. En pað sem er möguleg kveikja er líka mögulega steindautt. Ekkert er kveikja af eigin 
rammleik. Til pess að saga eins og Laxdœla geti orðið fóður fyrir gagnrýna hugsun er nauðsynlegt að nálgast hana sem opið tilboð um samræðu frekar en sem lokað safn staðreynda. Mjög margt af námsefni barna í skóla er alls ekki lagt upp sem slíkt tilboð um samræður heldur einmitt sem lokað safn staðreynda. Kennslubækur í öllum fögum eru uppfullar af svörum - réttum svörum - en gefa sjaldnar tilefni til opinna og ögrandi spurninga. Nám er of oft bundið pví að leggja á minnið eða tileinka sér færni sem er fyrirfram skilgreind en sjaldnar opið tilboð um samræðu par sem nemandinn hefur eitthvað verðugt og jafnvel óvænt fram að færa. Kennsluhættir eru pessu marki brenndir, peir eru of oft miðlun kennara til nemenda án pess að nemendur fái tækifæri til að kryfja eða vinna með efnið - eða finni yfirleitt fyrir nokkurri pörf á að gera pað. Í yfirgripsmikilli rannsókn á skólastarfi sem Gerður G. Óskarsdóttir leiddi ásamt fleirum segir m.a.:

Algengustu kennsluaðferðirnar voru annars vegar bein kennsla, með eða án samræðna við nemendur, og hins vegar kennsla par sem stuðst er við vinnubækur. Kennsluaðferðir sem gera meiri kröfur um pátttöku og ábyrgð nemenda (nemendamiðaðar aðferðir) voru talsvert fátíðari en aðferðir par sem kennarinn er í aðalhlutverki (kennarastýrðar aðferðir). (Gerður G. Óskarsdóttir, 2014, bls. 150)

Fornbókmenntirnar, eins og aðrar bókmenntir, má nota til að snúa pessu við, komast frá kennarastýrðum aðferðum til aðferða sem eru meira nemendamiðaðar. Og pegar pað tekst - pegar tekst að lesa fornbókmenntirnar sem opið tilboð um samræðu - pá eru pær kannski mikilvægasta fóðrið fyrir gagnrýna hugsun sem grunnskólar hafa aðgang að. Dær leggja ekki til reglur og skilgreiningar á rökvillum og öðrum hugtökum verklegrar eða formlegrar rökfræði enda verður enginn gagnrýninn hugsuður af pví einu að læra rökfræði - en pær skapa tækifæri til að rækta margvíslega rökfærni, samræðufærni, dýpka skilning á hugtökum um siðferði og stjórnmál, efla leitandi hugsun o.fl. Rökfræðin hjálpar örugglega til við að verða gagnrýnin manneskja en besta leiðin til að verða slík manneskja er að hugsa gagnrýnið um margvísleg efni, flókin efni en umfram allt efni sem maður hefur áhuga á.

\section{Laxdaela as food for critical thinking}

The sagas, like other good literature, provide an opportunity for dialogue on complicated and contested issues and are, therefore, a good source for teaching critical thinking. But is a book like The Laxdale Saga somehow better suited for the task than other literary works? I discuss two sides of this issue: One is philosophical and concerns the very idea of critical thinking, what it is and what "teaching critical thinking" might mean. The other side is practical and concerns the reality of overloaded schools which have to attend to various matters, have limited resources, are tied to firm structures and organization, and have teachers who may not have thought about critical thinking in particular, although experts in various other matters.

I argue that critical thinking is a certain kind of skill and the task of teaching critical thinking is a matter of developing or cultivating such skill. But what does such skill consist in? I argue that the skill is complex and in part made up of various virtues: intellectual virtues, moral virtues and performance virtues. Viewing critical thinking in this way locates its teaching within the tradition of character education. The question then becomes whether The Laxdale Saga is somehow well suited for character education.

To address this question, I attend to the practical side mentioned before. The Laxdale Saga has been read in schools for decades and is likely to maintain that status for decades to come. For this reason, it is easy to take it up as teaching material without, thereby, introducing something new into the school. Also, it makes sense to spend 
time and effort on preparing supporting material without having to worry that it will become outdated. Moreover, schools are likely to own class sets of the book, the teachers know the story, and there is knowledge as to the age group for which the story is suitable. These rather trivial aspects give a story like The Laxdale Saga an advantage over many other literary works. But the story itself has its own important features that contribute to it being a valuable source for character education.

The saga is ambiguous while, at the same time, discussing issues that the young people are dealing with themselves such as friendship, loyalty, honesty, forgiveness and relationships. Of course, the story also deals with hatred, deceit, trickery, dishonesty, spite, and revengefulness. By reading the story with virtues and vices such as those just mentioned in the foreground - rather than merely focusing on the plot - the story opens up to the young readers who find it modern and intriguing.

The purpose of reading The Laxdale Saga through the lens of virtue ethics is twofold. On the one hand, the ethical issues open up the story and turn it into an interesting sequence of events into which they delve. This opens up the possibility of using the story to discuss characters, their relationships, virtues, vices and more. Here, philosophy becomes a tool for exploring the story itself, relating to it and stimulating the imagination necessary for creative reading. On the other hand, the story is used to explore moral issues, ethical concepts, values and even theories, thus becoming a tool to stimulate moral imagination and trigger dialogue about contested moral issues.

When approaching The Laxdale Saga as an open invitation to dialogue, the status and role of the teacher is changed. On the one hand, the teacher maintains a traditional status as the expert who knows the story, selects words and concepts for further discussion, guides the pace of reading, etc. But, on the other hand, the teacher must be on the same footing as the students as he/she does not possess "the right interpretation" or "the right answer" but must enter the dialogue as a student of the story him or herself at the same level as his or her pupils. The teacher must, therefore, take on a double role; as a director of the activities and as a participant like any other.

One way for a teacher to get out of the traditional role of the mediator of knowledge and truth - a role which is antagonistic to the cultivation of critical thinking among students - is to take a literary work like The Laxdale Saga which calls for radical interpretative questions and approach it as an open invitation to dialogue on various matters, including moral issues.

Keywords: The Laxdale Saga, critical thinking, character education, virtues, moral development.

\section{Um höfundinn}

Ólafur Páll Jónsson (opj@hi.is) er prófessor í heimspeki við Menntavísindasvið Háskóla Íslands. Hann hefur m.a. ritað bækur og greinar um heimspeki menntunar og gagnrýna hugsun.

\section{About the author}

Ólafur Páll Jónsson (opj@hi.is) is a professor of philosophy at the School of Education, University of Iceland. His published works include papers and books on philosophy of education and critical thinking. 


\section{Heimildir}

Arthur, J. (2003). Education with character: The moral economy of schooling. London: RoutledgeFalmer.

Arthur, J., Kristjánsson, K., Harrison, T., Sanderse, W. og Wright, D. (2017). Teaching character and virtue in schools. London: Routledge.

Atla Harðarsonar. (2018). Ógæfa Bolla Dorleikssonar: Hugleiðing um hvernig Laxdæla saga leggur spurningar fyrir lesanda sinn en svarar peim ekki. Netla - veftímarit um uppeldi og menntun. Sérrit 2018 - Bókmenntir, listir og grunnpattir menntunar. Menntavísindasvið Háskóla Íslands. Sótt af http://netla.hi.is/serrit/2018/ bokmenntir_listir_menntun/02.pdf

Atli Harðarson, Ólafur Páll Jónsson, Róbert Jack, Sigrún Sif Jóelsdóttir og Póra Björg Sigurðardóttir. (2018). Laxdæla saga og siðferðilegt uppeldi í skólum. Netla - veftímarit um uppeldi og menntun. Sérrit $2018-$ Bókmenntir, listir og grunnpattir menntunar. Menntavísindasvið Háskóla Íslands. Sótt af http://netla.hi.is/ serrit/2018/bokmenntir_listir_menntun/01.pdf

Auerbach, L. (1998). Female experience and authorial intention in Laxdæla saga. Saga-book, 25(1), 30-52.

Ármann Jakobsson. (2005).Á ég að gæta bróđur míns? Innlifunin og Pórólfur Skalla-Grímsson. Skíma, 28(2), 35-41.

Bohlin, K. (2005). Teaching character education through literature: Awakening the moral imagination in secondary classrooms. New York: RoutledgeFalmer.

Carr, D. og Harrison, T. (2015). Educating character through stories. Exeter: Imprint Academic.

Dretske, F. (1991). Explaining behavior: Reasons in a world of causes. Cambridge MA: MIT Press.

Elsa Haraldsdóttir. (2011). Efling gagnrýninnar hugsunar og siðfraði i íslenskum skólum. Lokaskýrsla til Nýsköpunarsjóðs námsmanna. Reykjavík: Háskóli Íslands.

Eyja Margrét Brynjarsdóttir. (2013). Skynsemi eða rökleikni. Skírnir, 187(vor), 55-79.

Gerður G. Óskarsdóttir (ritstjóri). (2014). Starfshæettir í grunnskólum við upphaf 21. aldar. Reykjavík: Háskólaútgáfan.

Guðmundur Heiðar Frímannsson. (2018). Skólar og lýðraði. Reykjavík: Háskólaútgáfan.

Gunnar Karlsson. (2017). Laxdœla saga (stytt og endursögð) með skýringum og verkefnum eftir Ragnar Inga Aðalsteinsson og teikningum eftir Sigmund Breiðfjörð Porgeirsson. Kópavogi: Menntamálastofnun..

Helga Kress. (1980). 'Mjök mun pér samstaft pykkja.' Um sagnahefð og kvenlega reynslu í Laxdælasögu. Í Guðrún Gísladóttir, Svanlaug Baldursdóttir ogValborg Bentsdóttir (ritstjórar), Konur skrifa til heiðurs Önnu Sigurdardóttur (bls. 97-109). Reykjavík: Sögufélag.

Henry Alexander Henrysson. (2013). Skoðanir, siðferði, samfélag: Enn um gagnrýna hugsun. Netla - Veftímarit um uppeldi og menntun. Sótt af http://netla.hi.is/greinar/2013/ryn/001.pdf

Henry Alexander Henrysson og Páll Skúlason. (2014). Hugleiðingar um gagnrýna hugsun. Reykjavík: Háskólaútgáfan.

Henry Alexander Henrysson og Páll Skúlason. (2015). Siðferði og siðaboðskapur. Gagnrýnin hugsun og siðfræði: Efling gagnrýninnar hugsunar og siðfræði í skólum. Sótt af https://gagnryninhugsun.hi.is/

Laxdæla. (2010). Reykjavík: Mál og menning.

Noddings, N. (1992). The challenge to care in schools: An alternative approach to education. New York: Teachers College Press.

Noddings, N. (2002). Educating moral people. New York: Teachers College Press.

Noddings, N. og Shore, P.J. (1984). Awakening the inner eye: Intuition in education. New York:Teachers College Columbia University.

Ólafur Páll Jónsson. (2008). Gagnrýnar manneskjur. Hugur: Tímarit um heimspeki, 20(1), 98-112.

Ólafur Páll Jónsson. (2016). Sannfering og rök: Gagnrýnin hugsun, hversdagslegar skoðanir og rakalaust bull. Reykjavík: Háskólaútgáfan.

Ólafur Páll Jónsson og Póra Björg Sigurðardóttir. (2012). Lýdrexði og mannréttindi: Grunnpáttur menntunar á öllum skólastigum. Reykjavík: Námsgagnastofnun.

Páll Skúlason. (1987). Palingar. Reykjavík: ERGO. 
Róbert Jack. (2018a). Dygðir, siðferði og siðferðisproski: Að nota Íslendingasögur til mannkostamenntunar. Netla - veftímarit um uppeldi og menntun. Sérrit 2018 - Bókmenntir, listir og grunnpattir menntunar. Menntavísindasvið Háskóla Íslands. Sótt af http://netla.hi.is/serrit/2018/bokmenntir_listir_menntun/09.pdf

Róbert Jack. (2018b). Dygðirnar í Laxdæla sögu: Efniviður fyrir mannkostamenntun. Netla - veftímarit um uppeldi og menntun. Sérrit 2018 - Bókmenntir, listir og grunnpattir menntunar. Menntavísindasvið Háskóla Íslands. Sótt af http://netla.hi.is/serrit/2018/bokmenntir_listir_menntun/10.pdf

Rósa Marta Guðnadóttir. (2015). Kynngi orðsins: Rannsókn á miðlun menningararfsins í framhaldsskólum (óútgefin meistararitgerð). Sótt af http://hdl.handle.net/1946/21062

Dorsteinn Gylfason. (1996). Að hugsa á íslenzku. Reykjavík: Heimskringla.

Dóra Björg Sigurðardóttir. (2018,). Siðfræði í bókmenntakennslu. Netla - veftímarit um uppeldi og menntun. Sérrit 2018 - Bókmenntir, listir og grunnpattir menntunar. Menntavísindasvið Háskóla Íslands. Sótt af http:// netla.hi.is/serrit/2018/bokmenntir_listir_menntun/11.pdf

Ólafur Páll Jónsson. (2018).

Laxdæla sem fódur fyrir gagnrýna hugsun.

Netla - veftímarit um uppeldi og menntun. Sérrit 2018 - Bókmenntir, listir og grunnpættir menntunar.

Menntavísindasvið Háskóla Íslands.

Sótt af http://netla.hi.is/serrit/2018/bokmenntir_listir_menntun/06.pdf

https://doi.org/10.24270/serritnetla.2019.19 